\title{
Modern Trends and Development Problems of the Milk and Dairy Products Market in the Russian Federation
}

\author{
Aleksey B. MARTYNUSHKIN ${ }^{1 *}$, Vera S. KONKINA ${ }^{1}$, Julia B. KOSTROVA ${ }^{2}$, \\ Irina V. FEDOSKINA ${ }^{1}$, Nadezhda V. BARSUKOVA ${ }^{1}$, and Mikhail V. POLYAKOV ${ }^{1}$ \\ ${ }^{1}$ Ryazan State Agrotechnological University named after P.A. Kostychev, Ryazan, Russian Federation \\ ${ }^{2}$ Branch of the Private University Institution of Higher Education "Moscow University \\ named after S.Yu. Witte" in Ryazan, Ryazan, Russian Federation \\ *Correspondence: martinyshkin@mail.ru
}

\begin{abstract}
The relevance of this study is determined by the problem of providing the population with high-quality and safe dairy products that is becoming increasingly acute in the modern Russian economy. Milk and dairy products are the main food products and have a number of specific features due to the chemical and microbiological composition, which affects the quality and safety of products. The article summarizes the results of a some-year-long research by the authors in the field of formation and development of the milk and dairy products market in the Russian Federation. The purpose of this study is to analyze the current state of the milk and dairy products market in the Russian Federation and identify problems and development trends in the near future. The article details the features of the milk and dairy products supply in the Russian Federation, identifies the reasons for its change, analyzes the price dynamics, and critically considers measures of state support for the dairy industry. The analysis of trends and prospects for the development of the Russian market of milk and dairy products allows us to make the main conclusion that, unlike the markets of a number of other agricultural products, this market segment is one of the most dynamic, profitable and promising, but at the same time as other segments of food. The market cannot develop effectively without state support. The prevention of risks and the solution of emerging problems will require manufacturers, both raw milk and dairy products, to strengthen their work in ensuring high quality products while maintaining price stability.
\end{abstract}

Keywords: milk, dairy products, market, import substitution, milk quality.

\section{Introduction}

Milk and dairy products are one of the most consumed products not only in the world, but also in Russia. Milk and dairy products are a key source of necessary nutrients to ensure normal human life, providing the population with essential proteins and animal fats, macro and trace elements and vitamins that are not fully synthesized by the body itself. [1, p. 70] Over the past 20 years, the volume of production of raw milk in the Russian Federation has been approximately at the same level and vary from 30.5 to 34.5 million tons. The intensification and increase of production efficiency has led to the fact that in order to meet domestic demand in raw milk, less and less dairy cows have become required. [2, p. 61] From 1997 to 2018, the number of cows in Russia decreased 
by more than 6 million heads and amounted to 8.2 million heads. Moreover, more than $40 \%$ of the number of cows falls on agricultural organizations and only $15.4 \%$ - on peasant farms.

The agro-food policy pursued by the state allowed for the period 2013-2017 increasing milk production in all categories of farms by $1.1 \%$, including agricultural organizations by $11.6 \%$. [3, p.338] However, the achieved results could not radically change the existing negative trend in the dairy market. Despite a decrease in the share of dairy imports in the food balance by $4.6 \%$ to $18.2 \%$, the domestic market remains dependent on foreign producers and processors of milk, and the share of own resources in the dairy market does not reach the level of $90 \%$ established as a threshold indicator of the Food Security Doctrine. [4, p. 189]

\section{Materials and Methods}

One of the key sectors of the agro-industrial complex, which forms a significant amount of added value in the process of production and processing of agricultural products, is dairy cattle breeding, which not only plays an important role in the development of the agro-food market, but also provides jobs and largely determines the standard of living of the rural population. Therefore, the object of this study is the market of milk and dairy products of the Russian Federation in the dynamics of its development over the past 10 years. The main emphasis is on the period from 2015 to 2018 due to the fact that the introduction in 2014 of a ban on the import of dairy products from a number of foreign countries intensified the process of import substitution in the domestic dairy industry and provided a powerful incentive for the development of milk and dairy products in RF [5, p. 287] As the materials for writing the article, data from the Ministry of Agriculture of the Russian Federation and the results of their own research were used.

The process of performing the work was realized with some traditional research methods: monographic, economic-statistical, analytical, comparative analysis, a systematic approach to the study of economic phenomena. The manufacturers were segmented; the analysis of the internal and external environment of the milk and dairy products market in the Russian Federation was carried out. This article is a summary of the authors' many years of research on the problems of the formation and development of the Russian food market as a whole and its segment - the milk and dairy products market.

\section{Results}

Raw milk production is fairly evenly distributed throughout the country. Significant shares in the total production are occupied by the Republic of Tatarstan (5.8\%), the Republic of Bashkortostan (5.5\%), Krasnodar and Altai Krai (4.5\% each) [6, p. 39].

At the end of 2017, the rating of dairy enterprises was headed by EkoNiva, which in 2017 produced 300 thousand tons of milk and reached a milk yield of 1 thousand tons per day. By 2023-2024, the company plans to increase milk yield to 5 thousand tons a day. The total herd of EkoNiva, according to the company's own data, totals 110.5 thousand animals, including 51.8 thousand forage-fed cow cows. The second place in terms of milk production is occupied by "Agrocomplex" named after N. Tkachev that produced 171 thousand tons of raw milk in 2017. The total number of cattle of the enterprise is 78.8 thousand heads, including 27 thousand cows. In third place is for the Tatarstan holding 
"Ak Bars" with an output of 115 thousand tons of milk, a livestock of a dairy herd - 25 thousand heads, and a total livestock - 84 thousand animals [1, p. 71].

In the food and processing industry of the Russian Federation, a significant increase in the production volumes of most types of dairy products is noted today. [7, p. 92] This is primarily due to the release of a large share of the dairy market due to a reduction in imports due to the restriction on import of dairy products from a number of foreign countries into Russia since September 2014. An additional influence was exerted by the devaluation of the ruble, which also occurred in the second half of 2014, which led to a decrease in price competitiveness of imported products [8, p. 40].

From 2012 to 2017, the production of milk powder in Russia grew by 9\%, and whey powder - more than 2 times. During the entire analyzed period, only the volumes of condensed milk and cream production practically did not change. The dynamics of production of cheese, cheese products and cottage cheese in the Russian Federation was positive.

Despite the imposition of sanctions restrictions, imports of dairy products to Russia still have significant volumes. The total import of all types of dairy products in the Russian Federation in 2017 amounted to 1,092.7 thousand tons for a total value of $\$ 2,403.2$ million. In connection with the continued depreciation of the ruble in recent years, there has been a tendency to decrease an import volume of dairy products in physical terms with a simultaneous increase in value [9, p. 46].

The key supplier of dairy products to Russia is the Republic of Belarus. In 2017, its share in total imports of dairy products in the Russian Federation ranged from $71 \%$ to $94.7 \%$ for various categories of dairy products. In 2018, the Russian government also imposed restrictions on the import of certain categories of dairy products from the Republic of Belarus. Such a situation in the medium term can create favorable conditions for increasing the volume of its production within the country [10, p. 2025].

Among the permanent partners of the Russian Federation in the import of dairy products can also be named Argentina, Uruguay and New Zealand.

Export volumes of dairy products from Russia are much lower than volumes of its import. Thus, in 2017 they accounted 163.3 thousand tons, which is $9.0 \%$ (16.1 thousand tons) less than in 2016. The main markets for Russian dairy products are the countries of the Customs Union and some other post-Soviet countries (Ukraine, Kazakhstan, Kyrgyzstan, Turkmenistan, Georgia, Tajikistan, Uzbekistan, and Armenia). In small volumes, deliveries are made to China and the USA.

In the context of the depreciation of the Russian ruble, Russian dairy products became cheaper in the world currency, and, consequently, its competitiveness significantly increased both in the domestic and world markets [11, p. 8635].

The pricing of milk and dairy products in the Russian market is influenced not only by internal factors, but also by global trends [12, p. 35]. So, at the Global Daily Trade, worldwide prices for dairy products are set once per two weeks. As the analysis shows, stock prices for dairy products have been growing throughout 2019. From 2015 to 2019, the long-term dynamics of dairy product price indices only increased [13, p. 109].

Although it should be noted that after the imposition of sanctions and the development of import substitution processes, the influence of world price dynamics on the Russian 
dairy market somewhat decreased. In 2019, a higher degree of prices in the dairy industry was affected by an increase in the VAT rate to $20 \%$. Although the sale of dairy products is subject to VAT at a rate of $10 \%$, in other costs associated with the production and sale of products there is a rate of $20 \%$. At the same time, the higher the share of non-raw material costs in the cost structure, the more the increase in the base VAT rate translates into a price increase [14, p. 137].

In 2019, in the retail trade, the biggest price rise was observed for glazed curd cheeses (+ $25 \%$ compared to 2018$)$, processed $(+16 \%)$ and traditional $(+8 \%)$ cheeses, margarine $(+$ $6 \%)$, yoghurts $(+6)$, ice cream $(+6 \%)$ and butter $(+5 \%)$.

Talking about wholesale prices, it can be noted that in 2017 their growth was observed for most commodity items. At the same time, in 2018, the opposite trend is already noted [15].

When analyzing the dynamics of prices for milk and dairy products in the Russian Federation in the national currency over a longer period, one can see their significant increase. So, over the past 5 years, producer prices for milk have increased by more than $35 \%[15]$.

\section{Discussions}

One of the key problems that the milk and dairy products market has faced in recent years is the decrease in solvent consumer demand for final products [16, p. 202]. The reason for this was a significant decrease in real disposable incomes of population, which began in 2014 and continues to this day. In turn, this led to an increase in the production of milk-intensive products; since this segment is less affected by changes in consumer demand than, for example, whole milk. This is explained by the fact that in milk-intensive products, shelf life is usually longer and products are export-oriented in nature $[1$, p. 289].

From the consumers' point of view, a decrease in real disposable income and solvent demand for dairy products recorded during 2013-2017 formed a new consumption structure, characterized by consumer reorientation towards the acquisition of cheaper goods. Imported dairy products from countries that did not come under retaliatory economic measures by the Russian government, which increased in value after the ruble devaluation, became virtually uncompetitive in the domestic market. Along with increasing volumes of domestic production and processing of milk, this led to a reduction in import and the development of the import substitution process [17, p. 395].

State regulation of the milk and dairy products market in the Russian Federation is developing, adapting to its changing needs and undergoing significant changes in recent years. In July 2019, the Ministry of Agriculture of the Russian Federation developed new rules for providing state support to agricultural producers including in the dairy industry, which should begin to operate in 2020. To support the development of dairy cattle breeding, it is proposed to use the coefficient of increasing the share of sales and shipments to own processing, which will operate in the Far Eastern Federal District, Adygea, Tuva, Crimea and Sevastopol. Consequently, enterprises of most constituent entities of the Russian Federation, including the largest milk producing regions, will be deprived of increased subsidies [18, p. 140]. Such an approach can lead either to the need to increase regional state support, or to reduce the volume of milk production in 
these territories. Also, the updated version of the rules provides for the differentiation of the subsidy rate per 1 kilogram of milk sold, depending on the productivity indicator in the previous year. At the same time, similar differentiation for regions with different productivity indicators in the distribution of the limit is not provided. In our opinion, in order to maintain a favorable investment climate in the dairy industry, it would be advisable to postpone the considered innovations until at least 2022. This is due not only to the need to ensure food security, but also to the need to increase the export of dairy products to implement the May decree of the President of the Russian Federation [19, p. 101].

It should also be borne in mind that modern consumers have become more careful choosing a product in a store, and information on compliance with GOST and "quality marks" on packages no longer inspire confidence. In conditions of sufficient saturation of the Russian dairy market, further strengthening of state regulation of product quality should be expected. In this regard, producers of both raw milk and dairy products should strengthen more actively form and develop modern quality management systems for products.

\section{Conclusions}

The analysis made it possible to determine that further prospects for the development of the dairy industry will be associated with, first of all, increased intensification of production, the introduction of innovations at all stages of the product life cycle and the expansion of the product range. Restrictions on the import of dairy products from a number of foreign countries and the weakening of the national currency will continue to have a positive impact on market development. It should be borne in mind that at present, the sanction effect is already almost completely exhausted.

As negative factors, we can single out the decreasing solvent demand of the population of the Russian Federation, increasing the impact of food chains and large retailers on the pricing process for milk and dairy products, as well as the desire of processors to increase their desire to replace natural milk raw materials with components of plant or artificial origin.

At the moment, the milk and dairy products market is entering a new stage of development and should be aimed at solving such urgent problems as increasing production efficiency, reducing costs and increasing competitiveness at all stages, as well as developing exports and, most importantly, stimulating the consumption of dairy domestic products. In this situation government need to increase the authorities' responsibility by developing a comprehensive program aimed at increasing the physical and economic affordability of milk and dairy products for socially disadvantaged groups [1, p. 71]. As a mechanism for providing such assistance, international experience in issuing special food cards can be used, which not only increases the consumption of high-quality food products by these categories of citizens, but also ensures the formation of paid demand for the products of domestic agricultural producers. 


\section{References}

(1) Kostrova, Yu. B.; Martynushkin, A. B. Analysis of the Market of Milk and Dairy Products in Russia and Current Trends in Its Development (in Russian). Theoretical \& Applied Problems of Agro-Industry 2019, 42 (4), 69-72. https://doi.org/10.32935/2221-7312-2019-42-4-69-72.

(2) Belova, T. N.; Konkina, V. S. Processes of import substitution in the market of meat and dairy products in the context of economic policy (in Russian). Russian Economic Journal 2019, 3, 60-74. https://doi.org/10.33983/0130-9757-2019-3-6074.

(3) Konkina, V. S.; Martynushkin, A. B. Import Substitution Problems in the Dairy Cattle Breeding Industry (in Russian). In Materials of the 69th International Scientific and Practical Conference; RSATU: Ryazan, 2018; pp 337-340.

(4) Kostrova, Yu. B.; Martynushkin, A. B. Channels of Product Distribution and Logistics Risks in the Food Market of Russia. In Science in the modern information society: proceedings of an international scientific and practical conference; CreateSpace Independent Publishing Platform: North Charleston, 2014; pp 189-191.

(5) Belova, T. N. The Processes of Import Substitution in the Agro-Food Sphere: Success or Failure? (in Russian). Economy of Region 2019, 15 (1), 285-297. https://doi.org/10.17059/2019-1-22.

(6) Lyashchuk, Yu. O.; Martynushkin, A. B. Analysis of the milk market as an instrument of the risk management system in the dairy industry of the Central Federal District of Russia (in Russian). Economics of Agricultural and Processing Enterprises 2015, 3, 37-41.

(7) Rodin, I. K.; Martynushkin, A. B.; Polyakov, M. V.; Lyashchuk, Yu. O. Trends in the Production of Milk and Dairy Products in the Ryazan Region (in Russian). Bulletin of the Ryazan State Agrotechnological University 2013, 2 (18), 90-93.

(8) Konkina, V. S. Modeling of import substitution processes in the food market (in Russian). Economics of Agricultural and Processing Enterprise 2019, 10, 37-41.

(9) Kostrova, Yu. B.; Lyashchuk, Yu. O.; Martynushkin, A. B. Improving Milk Quality Control as a Factor of Food Security (in Russian). Theoretical \& applied problems of agro-industry 2019, 39 (1), 45-49. https://doi.org/10.32935/2221-7312-2019-39-145-49.

(10) Zavgorodnyaya, A. S.; Shashkova, I. G.; Konkina, V. S.; Romanova, L. V.; Mashkova, E. I.; Pikushina, M. Y. Adaptive Management of the Agricultural Enterprise in the Conditions of Environmental Uncertainty. Journal of Advanced Research in Dynamical and Control Systems 2018, 7 (Special Issue), 2022-2031.

(11) Konkina, $V_{\text {;; }}$ Shemyakin, A.; Babkin, I. Information and Software of Managing the Industry Cluster of the Region. In Proceedings of the 33rd International Business Information Management Association Conference; IBIMA: Madrid, 2019; pp 86328637. 
(12) Martynushkin, A. B. Agricultural Economics of Russia: Results of Accession to the WTO. In Research and Development - 2014: Materials of the X International Scientific and Practical Conference; "Byal GRAD-BG" Ltd: Sofia, 2014; pp 33-36.

(13) Konkina, V. S. Import substitution and implementation of export potential in the dairy market (in Russian). Agrarian Bulletin of the Upper Volga 2019, 1 (26), 103112.

(14) Mirzabalaeva, F. I.; Zabelina, O. V.; Alieva, P. R.; Konkina, V. S. Primary Areas of Labor Force Development in Russian Rural Territories (in Russian). Academy of Strategic Management Journal 16 (Special issue 1), 132-148.

(15) Ministry of Agriculture of the Russian Federation. Official website of the Ministry of Agriculture of the Russian Federation http://mcx.ru/ (accessed Feb 22, 2020).

(16) Martynushkin, A. B. State Support Measures as an Integral Element of the Restoration of Production Potential and the Agricultural Economy of Russia (in Russian). Bulletin of the Orenburg Agrarian University 2012, 3 (35-1), 202-205.

(17) Byshov, N. V.; Borychev, S. N.; Bakulina, G. N.; Fedoskin, V. V.; Fedoskina, I. V.; Pikushina, My. Systems analysis when evaluating and forecasting of agricultural enterprises. Religación. Revista de Ciencias Sociales y Humanidades 2019, 4 (18), 390-404.

(18) Krylatykh, E. N.; Fedorov, V. P. Food Security in the Context of Integration: Trends, Achievements, Threats (in Russian). Modern Europe 2013, 2 (54), 138-142.

(19) Konkina, V. S.; Martynushkin, A. B. Features of the Formation of the Domestic Market of Milk and Dairy Products in the Context of Ensuring Food Safety (in Russian). In Consumer market: quality and safety of goods and services: Materials of the national scientific and practical conference; RGATU: Ryazan, 2019; pp 100-104.

\section{Information about Authors}

Aleksey Borisovich MARTYNUSHKiN: Ph.D. in Economics, Associate Professor, Department of Economics and Management, Ryazan State Agrotechnological University named after P.A. Kostychev; 1 Kostychev Str., 390044, Ryazan, Russia; e-mail: martinyshkin@mail.ru.

Vera Sergeevna KONKiNA: Ph.D. in Economics, Associate Professor, Head of the Department of Marketing and Commodity Science of Ryazan State Agrotechnological University named after P.A. Kostychev; 1 Kostychev Str., 390044, Ryazan, Russia; e-mail: konkina_v@mail.ru.

Julia Borisovna KOSTROVA: Ph.D. in Economics, Associate Professor, Head of the Department of Business and Management, Branch of the Private University Institution of Higher Education "Moscow University named after S.Yu. Witte" in Ryazan; 5 Yablochkov Passage, Ryazan, 390023, Ryazan, Russia; e-mail: ubkostr@mail.ru.

Irina Vadimovna FEDOSKINA: Ph.D. in Economics, Associate Professor, Department of Economics and Management, Ryazan State Agrotechnological University named after P.A. Kostychev; 1 Kostychev Str., 390044, Ryazan, Russia; e-mail: fedoskina_prorektor@mail.ru. 
Nadezhda Vasilievna BARSUKOVA: Ph.D. in Economics, Associate Professor, Department of Economics and Management, Ryazan State Agrotechnological University named after P.A. Kostychev; 1 Kostychev Str., 390044, Ryazan, Russia; e-mail: hopeb2014@list.ru.

Mikhail Vladimirovich POLYAKOV: Senior Lecturer, Department of Economics and Management, Ryazan State Agrotechnological University named after P.A. Kostychev; 1 Kostychev Str., 390044, Ryazan, Russia; e-mail: peo1980@yandex.ru. 